\title{
Inovasi Perpustakaan dalam Mendukung Program E- Learning di Masa Pandemi Covid-19
}

\author{
Maniso Mustar \\ FK-KMK Universitas Gadjah Mada, Jl. Farmako Sekip Utara, Sinduadi, Mlati, Sleman, Yogyakarta, Indonesia
}

\begin{abstract}
Article Info

Received April 1, 2021

Revised April 11, 2021

Accepted May 6, 2021

Keywords:

- Library Innovation

- E-learning

- Learning Methods

- The Covid-19 Pandemic

Background: The Covid-19 pandemic has had various impacts on society. The impact on the world of education is one of them. The community is required to follow changes in learning patterns from face-to-face to long-distance which is often called e-learning. For this reason, various parties are needed to support this learning process, one of which is a library with the aim of supporting the learning process of the community in the midst of pandemic.

Methodology: This research uses descriptive research method. For data collection and analysis methods using literature studies from various references.

Results and Discussion: Raising awareness of the importance of education during a pandemic to the public, distance learning is a need that must be met with synergy of education providers, communities, governments and libraries. Innovation in circulation services, database services and e-resources, managing online library events, compiling credible information sources and coordinating among librarians are expected to support e-learning programs in Indonesia.

Conclusion: This study shows that e-learning is very much needed by society in current and future conditions. The education system can be implemented practically, efficiently and facilitates community learning. Library innovation to support e-learning is also very much needed to support the community learning process in the midst of a pandemic.
\end{abstract}

\section{Pendahuluan}

Secara historis, awal penyelenggaraan pendidikan, dilakukan dengan cara yang sangat tradisional dan sederhana, pembelajaran dimulai dengan cara menuliskan proses transfer pengetahuan di batu-batu, daun lontar dan kertas sebagai media untuk menambah pengetahuan. Semua dikerjakan dengan menggunakan media seadanya. Pendidikan yang merupakan usaha pembelajaran secara tradisional masih dinilai sebagai suatu pertemuan antara pendidik dan siswa yang masih bergerombol dalam suatu ruang atau kelas yang kemudian dikenal dengan konsep pembelajaran konvensional.

Dalam Undang-undang No. 20 Tahun 2003 Pasal 1 ayat 1 dirumuskan sebagai berikut:

"Pendidikan merupakan usaha sadar dan terencana untuk mewujudkan suasana belajar dan proses pembelajaran agar peserta didik secara aktif mengembangkan potensi dirinya untuk memiliki kekuatan spiritual keagamaan, pengendalian diri, kepribadian, kecerdasan, akhlak mulia, serta keterampilan yang diperlukan dirinya, masyarakat, bangsa dan negara. Pendidikan merupakan aspek yang sangat penting dan yang paling pokok dalam menentukan kemajuan dan kondisi suatu bangsa. Maju mundurnya suatu bangsa ada di tangan pendidikan. Sehingga baik buruknya sistem

\footnotetext{
* Corresponding author.

Email address: ariemaniso1205@ugm.ac.id
} 
pendidikan akan berdampak pada kualitas bangsa itu sendiri" (Republik-Indonesia, 2003).

Mengacu pada perundang-undangan di atas, kini pemerintah mendukung dan menerapkan pembelajaran yang lebih modern dan mengikuti perkembangan teknologi informasi dan komunikasi yang semakin berkembang dalam era industri ini. Adapun perkembangan yang diterapkan saat ini adalah mendorong dan mengubah pembelajaran dari konsepsi konvensional menjadi pembelajaran yang berbasis digital selaras dengan perkembangan teknologi informasi dan komunikasi (TIK), pembelajaran berbasis digital ini selanjutnya dikenal dengan istilah e-learning, yang salah satu kegiatannya dapat didukung melalui inovasi perpustakaan.

Kegiatan perpustakaan selama ini diyakini telah mendukung proses pembelajaran, namun sebagaian besar masih memberikan layanan secara tradisional dan menerapkan kunjungan secara langsung. Layanan informasi yang telah lazim disediakan oleh beberapa perpustakaan sebagai upaya mendukung proses pembelajaran secara e-learning selama ini lebih bertumpu pada kegiatan menyediakan koleksi digital yang dapat diakses melalui email, website atau melalui layanan koleksi elektronik yang disediakan secara terbatas dengan menggunakan intranet. Kedua layanan informasi perpustakaan di atas selama ini dirasa belum dapat membantu kegiatan pembelajaran jarak jauh karena banyaknya keterbatasan dalam hal akses dan koleksi yang masih berupa hard file yang masih tersusun di rak-rak koleksi perpustakaan. Untuk itu, perpustakaan diharap dapat melakukan inovasi untuk mendukung e-learning dengan melakukan diversifikasi layanan-layanan informasi seperti layanan sirkulasi online, layanan database dan e-resources, melakukan manajemen acara perpustakaan secara online, melakukan kompilasi sumber informasi yang kredibel dan melakukan koordinasi antar pustakawan.

Dengan demikian inovasi-inovasi layanan perpustakaan akan lebih dapat berperan dalam mendukung proses pembelajaran jarak jauh dalam memajukan pendidikan dan pengetahuan masyarakat secara masif di tengah situasi pandemi saat ini.

\section{Tinjauan Pustaka}

Pembelajaran berbasis digital ini adalah program yang diharapkan oleh pemerintah untuk dapat memecahkan berbagai permasalahan proses pembelajaran sesuai perundang-undangan yang berlaku dengan cara yang tepat untuk menghasilkan lulusanlulusan yang unggul berbasis teknologi bidang pendidikan. E-learning diharapkan dapat menjadi pondasi pendidikan di Indonesia untuk dapat mencetak generasi bangsa yang cerdas, terampil dan unggul. Pembelajaran ini diharapkan dapat sesuai dengan yang tercantum dalam Pasal 3 yang berbunyi, fungsi pendidikan nasional adalah mengembangkan kemampuan dan membentuk watak serta peradaban bangsa yang bermartabat untuk mencerdaskan kehidupan bangsa, bertujuan untuk berkembangnya potensi pelajar supaya menjadi manusia yang beriman dan bertakwa kepada Tuhan Yang Maha Esa, berakhlak mulia, sehat, berilmu, cakap, kreatif, mandiri, dan menjadi warga negara yang demokratis serta bertanggung jawab (Republik-Indonesia, 2003).

Ditinjau dari kepustakaan sebelumnya, bahasan ini menyatakan bahwa perpustakaan harus memahami faktor-faktor yang mempengaruhi adopsi teknologi baik di tingkat individu maupun di tingkat lingkungan. Sebelum menerapkan e-learning, maka perlu dilakukan studi kelayakan seperti identifikasi permasalahan untuk memahami manfaat TIK dalam mengimplementasikannya (Sungadi, 2018). Perpustakaan juga harus dikembangkan untuk mendukung pembelajaran elektronik atau e-learning (Suharti, 2019). 
Kedua sumber di atas sama-sama membahas mengenai perpustakaan dan pembelajaran jarak jauh (e-learning). Begitu juga penulis, dalam kesempatan kali ini akan membahas hal yang serupa, namun akan diperbaharui dengan bahasan yang lebih kreatif, inovatif dengan mengaitkan isu terkini yang berhubungan dengan topik pandemi Covid19 yang menuntut perubahan dan pembaharuan dalam proses pembelajaran.

Dalam pelaksanaan e-learning, pasti membutuhkan peran serta pihak lain sebagai pendukung yang merupakan suatu fasilitas pelengkap program e-learning, yakni perpustakaan. Perpustakaan dapat berperan dan bersinergi dalam mendukung pemerintah untuk membantu masyarakat dalam pelaksanaan e-learning di masa pandemi Covid-19 ini. Perpustakaan dapat menjadi ruang asyik untuk diskusi, ruang konsultasi, dan menjadi penyedia referensi online yang tidak dibatasi oleh ruang dan waktu (Mustar et al., 2019).

Pengaruh perkembangan teknologi informasi dan teknologi saat ini sudah memasuki berbagai bidang dalam kehidupan manusia tidak terkecuali dalam bidang Pendidikan (Muntinah, 2015). Menurut Wulandari \& Nugroho (2017), TIK hadir berupa internet, situs dan pembelajaran online yang dapat memberikan dampak besar untuk perpustakaan yang saat ini dalam masa transisi dari referensi cetak ke elektronik, dari pembelajaran konvensional ke pembelajaran online. Sementara Suharti (2019) menyatakan era disrupsi mengakibatkan munculnya berbagai inovasi dan kreativitas dalam segala bidang. Termasuk perpustakaan sebagai unsur penunjang Pendidikan, harus mempersiapkan sumber-sumber informasi untuk mendukung program e-learning.

Proses pembelajaran ini sangat tepat diterapkan oleh pemerintah dan masyarakat pada akhir-akhir ini. Dalam keadaan darurat yang harus membatasi berbagai pertemuan dan menjaga jarak, memakai masker dan selalu mencuci tangan untuk menghindari penularan virus, e-learning dan layanan perpustakaan secara online justru banyak memberikan manfaat dan kegunaan yang luar biasa untuk menunjang proses belajar mengajar dan pendidikan lainnya.

\section{Metode}

Metode pengumpulan data yang dilakukan adalah melalui metode library research, yaitu studi yang mempelajari berbagai buku referensi serta hasil penelitian sebelumnya yang sejenis yang berguna untuk mendapatkan landasan teori mengenai masalah yang akan diteliti (Sari \& Asmendri, 2020). Menurut penulis metode ini dapat mendukung pembahasan dalam penelitian ini, yaitu pembahasan mengenai konsep pembelajaran jarak jauh (e-learning) dan inovasi perpustakaan dalam mendukung kegiatan pembelajaran secara online. Data melalui buku dan artikel jurnal ditelusur melalui koleksi buku cetak di perpustakaan serta sumber-sumber digital e-journal atau melalui penelusuran pada google scholar, atau database e-resources dengan pencarian kata kunci yang relevan.

Data yang ditemukan melalui proses pengumpulan data library research dianalisis, disederhanakan dan disintesis atau saling dikaitkan satu dengan yang lainnya untuk kemudian hasil data yang ada disajikan di bagian hasil dan pembahasan pada penelitian ini. 


\section{Hasil dan Pembahasan}

\subsection{Hasil}

Membicarakan e-learning dan Covid-19 memang sangat menarik akhir-akhir ini. Mengapa begitu? Karena dalam kondisi pandemi saat ini, hampir semua fasilitas pendidikan seperti sekolah dan kampus di seluruh dunia ditutup dan tidak diijinkan untuk kegiatan belajar mengajar, padahal proses belajar mengajar tetap harus berjalan dan tidak boleh berhenti sama sekali. Kegiatan ini harus terus terselenggara meskipun dari rumah masing-masing siswa dengan menggunakan jaringan teknologi informasi dan komunikasi yang bersifat online, atau sering kita sebut e-learning.

Penelitian ini dapat dijadikan rujukan untuk meningkatkan kesadaran pentingnya pendidikan secara e-learning di masa pandemi kepada masyarakat, pembejaran jarak jauh adalah suatu kebutuhan yang harus dijalani dengan sinergitas antara penyelenggara pendidikan, masyarakat, pemerintah dan pustakawan.

\subsection{Pembahasan}

Untuk memberikan gambaran bagaimana inovasi perpustakaan dalam mendukung program e-learning pada masa pandemi Covid-19, akan dibahas melalui 4 (empat) poin yaitu pertama sejarah covid-19, kedua konsep e-learning, ketiga penerapan e-learning di masa pandemi dan keempat inovasi perpustakaan dalam mendukung program e-learning.

\subsubsection{Sejarah Covid-19}

Pandemi Corona Virus Diseases tahun 2019 (Covid-19) mewabah di seluruh dunia, termasuk Indonesia. Kemunculan virus corona di muka bumi begitu mengagetkan. Virus ini muncul pada bulan Desember 2019 di kota Wuhan, Tiongkok. Lalu virus corona terus menyebar dari kota ke kota di kawasan China, hingga akhirnya menyebar ke seluruh dunia, termasuk Indonesia. Pandemi baru ini disebabkan oleh human coronavirus, yang dirujuk sebagai acute respiratory syndrome yang ditengarai sebagai coronavirus 2 (SARSCoV-2), pandemi ini tidak hanya memiliki dampak besar pada sistem kesehatan dan ekonomi di semua benua tetapi juga menyebabkan perubahan radikal dari kebiasaan umum dan gaya hidup. Coronavirus novel $(\mathrm{CoV})$ memiliki probabilitas tinggi, asal zoonosis dan peran hewan dalam epidemiologi SARS-CoV-2 adalah sebagian besar masih belum diketahui.

Namun, CoVs sudah dikenal pada hewan sejak beberapa dekade, sehingga hewan coronavirologists memiliki keahlian hebat tentang cara menghadapi infeksi CoV pada hewan, yang dapat mewakili model untuk infeksi SARS-CoV-2 pada manusia. Pemahaman penuh tentang mekanisme yang mendorong evolusi CoV hewan akan membantu lebih memahami kemunculan, penyebaran, dan evolusi SARS-CoV-2 (Decaro \& Lorusso, 2020).

Dengan merebaknya pneumonia yang tidak diketahui di Wuhan, China, pada bulan Desember 2019, yakni sebuah coronavirus baru, Severe Acute Respiratory Syndrome Coronavirus 2 (SARS-CoV-2), membangkitkan perhatian seluruh dunia dan kemudian disebut Coronavirus Disease 2019 (COVID-19). Organisasi Kesehatan Dunia mendeklarasikan COVID-19 di China sebagai Emergency Health Public of Concern International. Virus ini menyababkan risiko teoritis penularan virus corona melalui transfusi produk darah labil. Karena semakin banyak infeksi tanpa gejala yang ditemukan di antara kasus COVID-19, pertimbangan keamanan darah dan coronavirus telah muncul terutama pada endemik area (Chang et al., 2020). 
Sementara itu, Kaul, (2020) dalam jurnal Current Medicine Research and Practice menyatakan, infeksi coronavirus telah muncul sebagai ancaman epidemi dan pandemi dalam dua dekade terakhir. Setelah pandemi influenza H1N1 pada tahun 2009, baru-baru ini didiagnosis betacoronavirus novel atau coronavirus pernafasan akut parah (SARS-CoV) -2 telah menyebar di 203 negara dan 5 wilayah benua utama. Organisasi Kesehatan Dunia (WHO) pun menyatakan ini adalah suatu kedaruratan kesehatan dalam masyarakat yang sangat diperhatikan di seluruh dunia.

Berdasarkan tinjauan literasi di atas, dapat disimpulkan bahwa pandemi Covid-19 sangat berbahaya dan dapat mengancam kelangsungan hidup umat manusia di muka bumi. Pandemi ini dapat merobohkan berbagai sektor kehidupan di dunia, baik sektor ekonomi, sosial, budaya, pendidikan bahkan sektor kesehatan manusia. Hal inilah yang membuat World Health Organization (WHO) pada tanggal 30 Januari 2020 menetapkan Coronavirus Disease (Covid-19) menjadi pandemi global. Pandemi yang membuat seluruh dunia gempar dan terdampak oleh kedahsyatan virus ini dengan korban yang sangat besar mulai dari materi hingga jutaan nyawa manusia.

Bagaimana pandemi Covid di Indonesia? Pandemi Covid-19 di Indonesia pun hampir sama menyerupai negara-negara lain di dunia. Penyebaran virus terjadi di berbagai kota yang kemudia terus merambah ke pulau-pulau di Indonesia. Menghadapi situasi ini, Pemerintah Republik Indonesia langsung tanggap dan menyikapi pandemi ini sebagai "Bencana Nasional pada 14 Maret 2020".

Pemerintah menghimbau kepada masyarakat untuk mengurangi aktifitas di laur rumah, termasuk himbauan bekerja dan belajar dari rumah yang saat ini popular dengan sebutan work from home (WFH) dan belajar dari rumah yang sering disebut Study From Home (SWH) sebagai bentuk kewaspadaan dan pencegahan penyebaran virus secara masif (Bahrudin, 2020). Himbauan ini ditengarai dengan seruan tinggal di rumah saja agar program social distancing dan physical distancing dapat dilaksanakan dengan tetap menjaga jarak aman antar warga negara di Indonesia termasuk belajar dari rumah yang saat ini dikenal dengan e-learning.

\subsubsection{E-learning}

Apa sih e-learning itu? TIK semakin pesat dan dapat mempengaruhi berbagai aspek kehidupan termasuk pendidikan. TIK dapat mendukung kegiatan belajar mengajar untuk memenuhi kebutuhan akan suatu konsep dan mekanisme pendidikan berbasis teknologi informasi.

Menurut Triluqman \& Sukirman (2009),

"Konsep yang kemudian terkenal dengan sebutan e-learning telah membawa pengaruh terjadinya proses transformasi pendidikan konvensional ke dalam bentuk digital, baik secara isi, materi dan sistemnya. Saat ini konsep e-learning sudah banyak diterima oleh masyarakat dunia, terbukti dengan maraknya implementasi e-learning khususnya di lembaga pendidikan baik sekolah, pelatihan, training dan perguruan tinggi".

E-learning adalah suatu rujukan secara umum dalam proses pembelajaran yang mengharuskan peserta didik untuk belajar di depan komputer atau perangkat lainnya yang tersambung dengan internet (Prawiradirga, 2013). Sementara Karwati, (2014) berpendapat e-learning ini merupakan suatu alternatif pembelajaran pada lembaga pendidikan yang terus meningkat di bidang teknologi komunikasi dan informasi. Infrastruktur di bidang telekomunikasi yang menunjang penyelenggaraan e-learning tidak 
hanya berada di kota besar, tetapi secara bertahap sudah memasuki kota-kota kecil seperti kabupaten.

Sedangkan menurut Wahyuni (2019), e-learning berasal dari ' $\mathrm{e}^{\prime}$ atau singkatan dari 'electronic' dan 'learning' yang berarti pembelajaran. Jadi e-learning adalah pembelajaran yang menggunakan bantuan perangkat elektronika, seperti komputer yang menyediakan fasilitas upload, download materi dan forum diskusi antara pengajar dan pembelajar yang dapat diakses kapan saja dan di mana saja.

Berdasarkan beberapa pendapat di atas, maka dapat disimpulkan, bahwa e-learning adalah proses pembelajaran yang dilakukan oleh pembelajar dan pelajar dengan menggunakan media yang tersambung dengan internet dengan fitur yang menyediakan fungsi unggah dan fungsi unduh mengenai materi pembelajaran, forum diskusi dan kajian suatu pembelajaran yang dapat diakses kapanpun dan di manapun.

\subsubsection{Penerapan e-learning dalam masa pandemi covid-19}

Tujuan pendidikan adalah untuk membentuk seseorang menjadi sempurna. Pendidikan menyediakan jalan untuk mencapai cita-cita mereka. Pendidikan juga membantu dalam menanamkan tanggung jawab sosial, norma, budaya dan etika. Inti utama dari pendidikan adalah untuk belajar dan menjalani proses untuk memperoleh pengetahuan atau keterampilan melalui studi, pengalaman, atau diajarkan (Radha et al., 2020).

Namun bencana sering kali menyisakan luka tersendiri bagi dunia pendidikan, demikian dengan pandemi COVID-19, kejadian ini memberikan dampak yang sangat mendalam pada pendidikan. Wabah virus berbahaya ini telah memaksa seluruh dunia institusi pendidikan tutup untuk mengontrol penyebaran virus. Kejadian ini membuat para pendidik profesional dan sivitas akademika memikirkan metode pengajaran alternatif selama penutupan ini. Dengan demikian, maka membuka jalan menuju pembelajaran berbasis web dan e-learning atau pembelajaran online. Di mana para profesional pengajar dan siswa terhubung secara virtual. E-learning cukup sederhana untuk memahami dan menerapkannya. Penggunaan desktop, laptop, atau smartphone dan internet merupakan hal utama yang merupakan komponen dan metodologi pembelajaran ini. E-learning memberikan pertumbuhan yang cepat dan terbukti menjadi yang terbaik dalam bidang pendidikan.

Dengan e-learning memungkinkan para pendidik mendapatkan cakupan yang lebih tinggi untuk mengkomunikasikan pesan kepada para siswa. Ini memastikan bahwa semua pelajar menerima jenis pelatihan yang sama dengan proses belajar. Namun, terlepas dari popularitas pendidikan online, sekelompok besar orang sengaja tetap tinggal jauh dari metode seperti itu, sebagian besar karena kesan yang salah.

Di Indonesia sendiri sebenarnya istilah pembelajaran jarak jauh dengan menggunakan media dan akses teknologi informasi dan komunikasi sudah berjalan sejak lama. Contoh nyata adalah proses pembelajaran yang telah diaplikasikan Universitas Terbuka. Universitas ini telah lama berhasil meluluskan ribuan sarjana dalam berbagai bidang dengan menggunakan sistem pebelajaran online yang mulai popular akhir-akhir ini. Pendidikan jarak jauh berbasis TIK pun diberlakukan oleh pemerintah untuk menekan penyebaran Covid-19 supaya paparan virus ini tidak merajalela di negeri Indonesia (Rachmaningsih, 2020).

Tidak semudah yang dibayangkan, ternyata sistem e-learning ini banyak penolakan baik dari para pendidik, tenaga kependidikan dan siswa karena mereka merasa terbebani oleh tingginya biaya untuk melakukan proses pembelajaran ini. Pemerintah melalui Kementerian Pendidikan dan Kebudayaan pun memberikan bantuan kepada pendidik, 
tenaga kependidikan dan siswa supaya proses pembelajaran tetap berjalan dengan lancar dan angka penyebaran virus juga terkendali.

\subsubsection{Inovasi Perpustakaan dalam Mendukung Program E-learning}

Perpustakaan seperti yang dipertimbangkan oleh Presiden Republik Indonesia sebagai berikut:

"Bahwa dalam rangka mencerdaskan kehidupan bangsa sebagaimana diamanatkan dalam Undang-Undang Dasar Negara Republik Indonesia Tahun1945, perpustakaan sebagai wahana belajar sepanjang hayat mengembangkan potensi masyarakat agar menjadi manusia yang beriman dan bertakwa kepada Tuhan Yang Maha Esa, berakhlak mulia, sehat, berilmu, cakap, kreatif, mandiri, dan menjadi warga negara yang demokratis serta bertanggung jawab dalam mendukung penyelenggaraan Pendidikan nasional" (Undangundang Republik Indonesia No 43, 2007).

Perpustakaan sebagai wahana belajar sepanjang hayat untuk mengembangkan potensi masyarakat, memiliki peran yang sangat penting dan strategis untuk mendukung proses pembelajaran elektronik (e-learning) yang sangat dibutuhkan oleh masyarakat dalam situasi pandemi Covid-19 akhir-akhir ini. Dalam situasi ini perpustakaan sangat dibutuhkan oleh masyarakat untuk mendukung mereka dalam melaksanakan proses pembelajaran secara online.

Menurut Suharti (2019), perpustakaan saat ini semakin dituntut untuk mengikuti perkembangan teknologi yang semakin canggih. Pola pendidikan berubah dari tradisional ke model elektronik, hal ini membutuhkan informasi-informasi digital. Perpustakaan harus bersiap untuk mendukung dunia pendidikan dengan mempersiapkan sumbersumber informasi untuk mendukung pembelajaran elektronik.

Wulandari \& Nugroho (2017) mengemukakan teknologi informasi dapat merubah sektor pendidikan yang pada awalnya dikerjakan manual dan berkembang menjadi sistem online (e-learning). Sistem e-learning membantu mahasiswa untuk mendapatkan materi kuliah maupun mengumpulkan tugas melalui website. Pembelajaran model lama akan terlihat berbeda dengan pembelajaran online (e-learning) yang dapat dilihat dari segi ruang dan waktu yang dapat digunakan untuk berinteraksi antara mahasiswa dan dosen.

Sedangkan menurut Muntinah, (2015), e-learning adalah sistem pendidikan modern yang telah dipraktikan di dunia. E-learning bisa memerankan fungsi pendidikan dari sebuah perpustakaan digital. Fungsi pendidikan dari sebuah perpustakaan akan berjalan lebih efektif dan efisien serta keberadaan perpustakaan serta memudahkan para pengguna dalam mengakses perpustakaan tanpa dibatasi oleh ruang dan waktu.

Berdasarkan beberapa pendapat di atas, dapat disimpulkan bahwa perpustakaan dapat melakukan inovasi untuk mendukung proses pembelajaran secara online sebagai wahana untuk penyediaan bahan pembelajaran secara online yang dapat memberikan kemudahan dalam kegiatan belajar mengajar yang diselenggarakan secara online (e-learning).

Adapun beberapa inovasi layanan perpustakaan yang dapat dikembangkan untuk mendukung proses pembelajaran jarak jauh saat ini antaralain:

\subsubsection{Inovasi Layanan Sirkulasi}

Layanan sirkulasi perpustakaan dalam mendukung e-learning saat ini harus dilakukan inovasi, layanan tidak dilakukan seperti biasanya. Pemustaka melakukan peminjaman melalui layanan drive-trhu. Layanan drive-thru adalah layanan yang berbentuk suatu tempat-tempat khusus atau sebuah loket untuk melayani kebutuhan pemustaka tanpa harus turun dari kendaraan (Putra, 2021). 
Sementara itu, untuk proses pengembalian bahan pustaka dapat dilakukan secara online yakni dengan cara mengirim buku ke perpustakaan dengan menggunakan jasa transportasi online, sedangkan untuk perpanjangan peminjaman dapat melalui layanan sosial media seperti Instagram, WhatApp Chat, email atau SMS kepada petugas layanan sirkulasi (Mustar, 2020).

\subsubsection{Layanan Database dan e-Resources}

Layanan database dan e-resources yang dilanggan oleh perpustakaan dapat diberikan kepada seluruh sivitas akademika secara online baik melalui petugas perpustakaan maupun akun khusus untuk seluruh aktivis akademis. Dengan layanan ini sivitas akademika tetap bisa mengakses dan mengunduh database dan e-resources yang telah dilanggan sebagai bahan belajar mengajar maupun penelitian kapanpun dan dari manapun. Layanan ini dapat menjadi inovasi suatu perpustakaan dalam mendukung pembelajaran jarak jauh dengan menyediakan referensi online secara tepat dan efisien.

\subsubsection{Melakukan Manajemen Acara Perpustakaan Secara Online}

Berbagai acara perpustakaan selama ini banyak yang dilakukan secara langsung (luring) berupa berbagai workshop dan pelatihan dengan instruktur dan pemateri dari tenaga perpustakaan. Untuk mendukung pembelajaran jarak jauh, maka perpustakaan dapat melakukan inovasi dengan mengubah berbagai acara yang tadinya offline menjadi online supaya dapat diikuti oleh seluruh sivitas akademika dari manapun, tanpa harus hadir ke perpustakaan atau tempat penyelenggaraan acara.

\subsubsection{Melakukan Kompilasi Sumber Informasi yang Kredibel}

Perpustakaan memiliki peran untuk turut memberikan informasi yang sehat dan up to date kepada masyarakat, terutama sivitas akademika. Perpustakaan dapat membuat kompilasi bahan ajar dan pembelajaran sesuai yang telah disepakati oleh komite pengajaran sesuai kurikulum yang berlaku. Kompilasi ini bisa juga dibagikan kepada masyarakat lain yang membutuhkan seperti peneliti dan pencari ilmu yang lain.

Tenaga perpustakaan dapat melakukan download e-journal dan e-book yang telah dilanggan oleh institusi, kemudian membuat metadata untuk diunggah ke laman khusus yang telah disiapkan supaya dapat diakses secara mudah oleh sivitas akademika untuk menunjang proses pembelajaran secara online.

\subsubsection{Melakukan Koordinasi antar Pustakawan}

Perpustakaan dapat melakukan koordinasi antar pustakawan yang meliputi pembagian dan pelaksanaan tugas antar pustakawan di perpustakaan. Membuat pembagian tugas tenaga perpustakaan untuk memberikan layanan secara integrasi mulai dari perencanaan, pemilihan konten, pengumpulan materi, pengunggahan konten sampai dengan melayankan konten perpustakaan yang dapat dilayankan secara mudah dan efisien kepada sivitas akademika.

Dengan inovasi di atas, maka kegiatan belajar mengajar tetap dapat terselengara dengan baik meskipun berjalan secara online tanpa harus terhalang oleh ruang dan waktu sesuai dengan anjuran pemerintah dan undang-undang pembelajaran yang ditetapkan. 


\section{Kesimpulan}

E-learning merupakan kegiatan belajar mengajar secara online yang dapat membantu proses pendidikan yang lebih efektif. Praktik pembelajaran secara konvensional yang selama ini kita jalankan, ternyata dapat gantikan dengan pembelajaran yang memanfaatkan sumber elektronik, perangkat elektronik dan jaringan internet berbasis TIK.

Perpustakaan dapat berperan dalam mendukung program e-learning dengan melakukan inovasi layanan sirkulasi, layanan database dan e-resources, melakukan manajemen acara perpustakaan secara online, melakukan kompilasi sumber informasi yang kredibel dan melakukan koordinasi antar pustakawan untuk mendukung kegiatan elearning.

Kegiatan belajar jarak jauh (e-learning) ini, sangat dibutuhkan oleh masyarakat dalam kondisi pandemi Covid-19 seperti sekarang ini, maupun dalam masa yang akan datang dengan dukungan sumber daya manusia yang unggul dengan memanfaatkan teknologi yang canggih. Sistem pendidikan dapat dijalankan secara praktis, efisien dan memudahkan pembelajaran masyarakat. Inovasi perpustakaan untuk mendukung elearning juga sangat diperlukan untuk menunjang proses pembelajaran masyarakat di tengah pandemi.

\section{Daftar Pustaka}

Bahrudin, M. (2020). Bagaimana Pustakawan Bekerja di Tengah Pandemi Covid-19? Pustakawan Blogger Indonesia, Corona Virus Diseases. https://www.pustakawan.web.id/2020/03/pustakawan-di-tengah-pandemikcovid19.html

Chang, L., Yan, Y., \& Wang, L. (2020). Coronavirus Disease 2019: Coronaviruses and Blood Safety. Transfusion Medicine Reviews, September 2012, 2-7. https://doi.org/10.1016/j.tmrv.2020.02.003

Decaro, N., \& Lorusso, A. (2020). Novel human coronavirus (SARS-CoV-2): A lesson from animal coronaviruses. Veterinary Microbiology, 244(March), 108693. https://doi.org/10.1016/j.vetmic.2020.108693

Karwati, E. (2014). Pengaruh Pembelajaran Elektronik (E-Learning) terhadap Mutu Belajar Mahasiswa. Jurnal Penelitian Komunikasi, 171), 41-54. https://doi.org/10.20422/jpk.v17i1.5

Kaul, D. (2020). An overview of coronaviruses including the SARS-2 coronavirus Molecular biology, epidemiology and clinical implications. Current Medicine Research and Practice, $X X X X, 1$-11. https://doi.org/10.1016/j.cmrp.2020.04.001

Muntinah, D. (2015). Penerapan Metode E-learning dan Layanan Sirkulasi Sebagai Model Pembangunan Digital Library. Libraria, 3(1), 138-147.

Mustar, M. (2020). Layanan Perpustakaan di Tengah Pandemi Covid-19. In Buku KMP 9, Pustakawan, Perpustakaan, dan Kebencanaan(Vol. 9, pp. 193-213).

Mustar, M., \& Nashihuddin, W. (2019). Dokter Pustaka: Layanan Informasi Online Bidang Kesehatan Alumni Fakultas Kedokteran, Kesehatan Masyarakat dan Keperawatan Universitas Gadjah Mada Yogyakarta. Lentera Pustaka: Jurnal Kajian IImu $\begin{array}{lllll}\text { Perpustakaan, Informasi Dan } & 97 .\end{array}$ https://doi.org/10.14710/lenpust.v5i2.25944

Prawiradirga, D. S. et. al. (2013). Mozaik Pendidikan Teknologi E-learning (1st ed.). Pranamedia Group.

Putra, A. W. et. al. (2021). Inovasi Layanan Drive-thru Perpustakaan untuk Meningkatkan 
Budaya Literasi (Studi di Dinas Perpustakaan dan Kearsipan Provinsi Jawa Timur). Publika, 2(2), 25-38.

Rachmaningsih, D. M. (2020). Perespektif Milenial: Pendidikan Jaraj Jauh(1st ed., Vol. 1). Penerbit Universitas Terbuka.

Radha, R., Mahalakshmi, K., Kumar, V. S., \& Saravanakumar, A. R. (2020). E-Learning during Lockdown of Covid-19 Pandemic: A Global Perspective. International Journal of Control and Automation, 13(4), 1088-1099.

Republik-Indonesia. (2003). Undang-undang Republik Indonesia Nomor 20 Tahun 2003 Tentang Sistem Pendidikan Nasional. 0932(1), 147-173.

Sari, M., \& Asmendri. (2020). Penelitian Kepustakaan (Library Research) dalam Penelitian Pendidikan IPA. NATURAL SCIENCE: Jurnal Penelitian Bidang IPA Dan Pendidikan IPA, G(1), 41-53. https://ejournal.uinib.ac.id/jurnal/index.php/naturalscience/article/view/1555/1159

Suharti. (2019). Perpustakaan Digital Pendukung E-learning di Era Disrupsi. Buletin Perpustakaan Universitas Islam Indonesia, 2(1), 19-29.

Sungadi. (2018). Peran Perpustakaan Dalam Pembelajaran Online. Buletin Perpustakaan Universitas Islam Indonesia, 1(2), 75-95.

Triluqman, H., \& Sukirman. (2009). Pengembangan Sistem Pembelajaran Online Berbasis Moodle Di Jurusan Kurikulum Dan Teknologi Pendidikan Universitas Negeri Semarang. Lembaran IImu Kependidikan, 38(1), 27-34.

Undang-undang Republik Indonesia No 43. (2007). Undang-Undang Republik Indonesia Tentang Perpustakaan.

Wahyuni, D. et. al. (2019). Sistem Informasi E-Learning AMIK Imelda Untuk Meningkatkan Mutu Pembelajaran. JATILIMA, 01(2).

Wulandari, N., \& Nugroho, E. (2017). E-Learning: Implikasinya Terhadap Pelayanan Perpustakaan Perhuruan Tinggi dan Peran Pustakawan. Berkala IImu Perpustakaan Dan Informasi. https://doi.org/DOI: http://10.22146/bip.26199 